\title{
膝蓋腱炎(ジャンパー膝)の良導絡電気鍼治療 と追跡調查
}

要 約

膝蓋腱炎はジャンプ、ランニング、サイク リング、サッカーのように、膝の収縮筋を繰 り返し多用するタイプのスポーツ選手によく 起こる障害である。この研究ではステージ 3 の膝蓋腱炎患者58例（66膝）について良導絡 の治療効果を評価した。痛みが完璧に消え、 以前の運動レベルまで回復した例は 43 人 $(74.1 \%)$ である。この結果は良導絡治療が膝蓋腱炎に 効果的な方法でありしかも簡単な処置で、費 用もかからず、鎮痛を得るための治療期間も 少なく良いという利点がある。

\section{紹 介}

膝蓋腱炎は膝の収縮筋を繰り返し多用する タイプのスポーツ選手によく起こる障害であ る。

“ジャンパー膝”という用語は1973年にBlazina が過度のジャンプ競技の選手に対して表現し たものである。この病状はBlazinaと後にROELS により改良された 4 ステージに分類される。 ステージ 1 : 運動を始める時の痛み、ステー ジ 2 : 運動を始める時に痛みがあり、ウォー ミングアップ後に消え、さらに運動終了後に 再度痛みが出る。ステージ 3 : 運動の前も後 にも痛みが持続し患者はスポーツを行うこと ができない。ステージ 4 ：完全な膝蓋腱の断 裂が起きた状態。患者は長い時間座っている 時に痛みを感じ大腿四頭筋をリラックスさせ る為に膝を伸ばしたくなる、また膝をかがむ 姿勢をとる時や、階段、坂を上り下りすると
きに痛みを感じる。

そこで今回の目的はステージ 3 の膝蓋腱炎 患者の治療に良導絡を用いその実績を発表す ることにある。

\section{素材と方法}

今回の研究では患者58人（66の膝）を対象 とした、内訳は男性 40 人と女性 18 人で平均年 令は26藏（17～50歳）であった。患者は痛み が出て以来整形外科の専門医にかかっており、 良導絡治療以前にかかっていた期間は平均 14 ケ月（1８４ケ月）であった。全ての患者 はステージ 3 の症状を呈していた。

右膝の障害は32例 $(55.1 \%)$ で、左膝の障 害は18例 $(31.0 \%)$ 、両膝は 8 例 $(13.9 \%)$ で ある。〈表 1 参照〉

\section{表 1. 膝蓋靶带炎 左右発生頻度}

\begin{tabular}{|c|c|c|}
\hline 障害价 & 乗生件数 & バーセンテーシ \\
\hline 右 & 32 & $55.10 \%$ \\
\hline 左 & 18 & $31.00 \%$ \\
\hline 両甽 & 8 & $13.90 \%$ \\
\hline
\end{tabular}

痛みの場所は膝蓋骨の下極が38例 $(65.5 \%)$ ， 上極が 9 例 $(15.5 \%)$ 、両極が11例 $(19 \%)$ で あった。〈表 2 参照〉

表2. 膝蓋靬帯炎 障害部位発生頻度

\begin{tabular}{|c|c|c|}
\hline 碚害杬 & 発生件数 & パーセンデーシ \\
\hline 上糧 & 38 & $65.50 \%$ \\
\hline 下糧 & 9 & $15.50 \%$ \\
\hline 上下両桠 & 11 & $19.00 \%$ \\
\hline
\end{tabular}

*ブラジル

キーワード：膝、膝蓋腱炎、腱炎、電気鍼、スポーツ障害、無痛覚症 
58例のスポーツの種類はランニング16例(28\%)、 サッカー8例 $(14 \%)$, 体操 7 例 $(12 \%)$ 、バ レー7例 $(12 \%) 、$ 、゙レーボール 6 例 $(10 \%)$ 、 テニス 4 例 $(7 \%)$ 、バスケットボール 3 例 $(5 \%)$ 、 その他 7 例 $(12 \%)$ であった。〈表 3 参照〉

\section{表3. 膝蓋靶帯炎 発生スポーツ}

\begin{tabular}{|c|c|c|}
\hline スポーツ & 患者数 & ペーセテデーシ \\
\hline ランニング & 16 & $28 \%$ \\
サッカー & 8 & $14 \%$ \\
体 & 7 & $12 \%$ \\
バレー & 7 & $12 \%$ \\
ハレーボール & 6 & $10 \%$ \\
テニス & 4 & $7 \%$ \\
ハスケッドール & 3 & $5 \%$ \\
その他 & 7 & $12 \%$ \\
\hline
\end{tabular}

痛みの強さの評価は視覚的アナログスケー ル (VAS)によって行う。VASは10センチの 線を用いて、無痛状態(学術用語でpain absence) を端に設定し、反対側に耐えられない痛み （unbearable pain）を設定する。患者が痛み の強さを表現するために 0 から10までのVAS 線上の目盛りに垂直の線を引くことで数値化 される。

今回の研究で対象とした全ての患者はそれ まで受けた数回の治療で良い結果がえられな かった人から応募された。

我々は日本製のTormeter IW5010Bという

機械と、ステンレス製の鍼をオートクレープ で殺菌し、適当な長さの鍼管を用いた。Tormeter IW5010Bを使う事によって、膝蓋骨の上極や 下極にある皮㲊の電気抵抗が低い点を探すこ とができる。鍼はこれらの点で骨膜に当たる までに垂直に刺す。銊を通して $12 \mathrm{~V}, 100 〜 150$ $\mathrm{mA}$ の直流電流をそれぞれ 7 秒間流す。膝蓋骨 の上極や下極に 2 から 7 箇所のポイント探す。 中谷先生はこれらの電流が多く流れる点（皮 䖉の電気抵抗が低い点）を反応良導点と命名 した。ほとんど場合反応良導点は触診での感 受性が高い点と一致する。

治療に有効な回数は週に $3 \sim 5$ 回、 $2 \sim 5$ 週の期間で治療効果が現れる。患者 35 人 (66\%) は 1 ～10回の治療を受け、20人 (34\%) は11〜 20 治療で、3人 $(5 \%)$ は 20 回以上の治療
を受けた。

\section{結 果}

我々が作った評価基準は次の通りである： 著効……患者が痛みを感じずに以前の活動 に戻れた場合。

有効……患者のVASがスポーツをしている 間に 4 以上から $2 \sim 3$ に改善した もの。

不变……患者の痛みが取れなかったか、以 前のスポーツ競技に戻ったときに 機能制限が残つた場合。

著効 : 43例 $(73.4 \%)$ 、有効 : 10例 $(17.2 \%)$ 、 不変 : 5 例 $(8.7 \%)$ 。不変の患者は外科に送 る。完全に痛みが取れた患者は 43 例 $(74.1 \%)$ 。 追跡調査が可能な患者は58の治療例のうち 41 人 $(70.6 \%)$ で電話連絡が可能な患者である。 追跡調查は $3 \sim 169$ ヶ月 (平均72.0ヶ月) 行 つた。41人の追跡調査をしている患者のうち、 37 例の患者は痛みが完全に消え（VAS $=0)$, 37 以外の残りの患者は 8 例については時間が たった後に痛みが消えた。これらの患者につ いて治療終了時の平均のVAS $=2.2(1 \sim 3)$ で追跡調査時にも完全な痛みの消失 $(\mathrm{VAS}=$

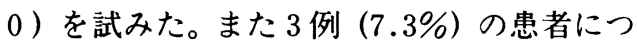
いて,改善はみられなかった。更に 1 例の患者 については痛みが悪化した。〈表 4〉

良導絡での平均の治療期間は73.1ヶ月（3〜 168ヶ月）であった。〈表 4〉 
表 4。追跡調查

\begin{tabular}{|c|c|c|c|c|c|}
\hline 番昼 & イニシャル & 性別 & 年齢 & 追跡調查 & 痛みの評価: 治療終了時 $\rightarrow$ 追跡調査 \\
\hline 1 & & $\pi$ & 25 & 169ヶ月 & VAS $=0 \rightarrow 0$ \\
\hline 2 & & $\sigma^{7}$ & 46 & 156ヶ月 & VAS $=0 \rightarrow 0$ \\
\hline 3 & & ס & 18 & 132ヶ月 & VAS $=0 \rightarrow 0$ \\
\hline 4 & & व & 28 & 129ヶ月 & VAS $=0 \rightarrow 0$ \\
\hline 5 & & $\sigma^{7}$ & 26 & 129ヶ月 & VAS $=2 \rightarrow 0$ \\
\hline 6 & & $\sigma^{x}$ & 35 & 127ヶ月 & VAS $=0 \rightarrow 0$ \\
\hline 7 & & ه & 16 & 126ヶ月 & VAS $=0 \rightarrow 0$ \\
\hline 8 & & 우 & 9 & 121ヶ月 & VAS $=0 \rightarrow 0$ \\
\hline 9 & & ه & 21 & 120ケ月 & VAS $=0 \rightarrow 0$ \\
\hline 10 & & 우 & 25 & 119ヶ月 & VAS $=2 \rightarrow 0$ \\
\hline 11 & & 우 & 29 & 118ヶ月 & VAS $=4 \rightarrow 6$ \\
\hline 12 & & $\sigma^{x}$ & 28 & 118ヶ月 & VAS $=0 \rightarrow 0$ \\
\hline 13 & & ه & 38 & 112ヶ月 & VAS $=0 \rightarrow 0$ \\
\hline 14 & & 8 & 44 & 81ヶ月 & VAS $=0 \rightarrow 0$ \\
\hline 15 & & क & 29 & 80ケ月 & VAS $=0 \rightarrow 0$ \\
\hline 16 & & 우 & 50 & 78ヶ月 & VAS $=1 \rightarrow 0$ \\
\hline 17 & & $\sigma^{7}$ & 19 & 78ケ月 & VAS $=0 \rightarrow 0$ \\
\hline 18 & & 우 & 47 & 77ヶ月 & VAS $=0 \rightarrow 0$ \\
\hline 19 & & q & 49 & 72ヶ月 & VAS $=0 \rightarrow 0$ \\
\hline 20 & & $\sigma^{7}$ & 20 & 68ヶ月 & VAS $=0 \rightarrow 0$ \\
\hline 21 & & व & 22 & 64ヶ月 & VAS $=0 \rightarrow 0$ \\
\hline 22 & & 우 & 50 & 60ヶ月 & VAS $=0 \rightarrow 0$ \\
\hline 23 & & 우 & 50 & 57ヶ月 & VAS $=3 \rightarrow 0$ \\
\hline 24 & & 우 & 17 & 53ヶ月 & VAS $=2 \rightarrow 2$ \\
\hline 25 & & 8 & 23 & 48ヶ月 & VAS $=3 \rightarrow 0$ \\
\hline 26 & & ه & 37 & 46ヶ月 & VAS $=0 \rightarrow 0$ \\
\hline 27 & & 우 & 48 & 43ヶ月 & VAS $=0 \rightarrow 0$ \\
\hline 28 & & 우 & 25 & 43ヶ月 & VAS $=2 \rightarrow 2$ \\
\hline 29 & & 우 & 42 & 42ヶ月 & VAS $=0 \rightarrow 0$ \\
\hline 30 & & o & 17 & 41ヶ月 & VAS $=0 \rightarrow 0$ \\
\hline 31 & & 8 & 50 & 36ヶ月 & VAS $=2 \rightarrow 0$ \\
\hline 32 & & 우 & 50 & 36ヶ月 & VAS $=0 \rightarrow 0$ \\
\hline 33 & & 우 & 19 & 32ヶ月 & VAS $=1 \rightarrow 1$ \\
\hline 34 & & व & 50 & 28ヶ月 & VAS $=0 \rightarrow 0$ \\
\hline 35 & & 우 & 22 & 28ヶ月 & VAS $=0 \rightarrow 0$ \\
\hline 36 & & वृ & 35 & 23ヶ月 & VAS $=3 \rightarrow 0$ \\
\hline 37 & & d & 49 & 22ヶ月 & VAS $=2 \rightarrow 0$ \\
\hline 38 & & or & 25 & 22ヶ月 & VAS $=0 \rightarrow 0$ \\
\hline 39 & & 우 & 19 & 9ヶ月 & VAS $=0 \rightarrow 0$ \\
\hline 40 & & $\sigma^{7}$ & 50 & 5ヶ月 & VAS $=0 \rightarrow 0$ \\
\hline 41 & & 우 & 27 & 3ヶ月 & VAS $=0 \rightarrow 0$ \\
\hline
\end{tabular}

\section{考 察}

昨年滕蓋腱炎が増加したことは、スポーツの 激しい練習を行う人が増えたことと、病状に関 しての理解が進んだことにによると思われる。 診断には膝蓋骨の上極か、上下 3 分の 1 の 中央部、または下極（膝蓋腱）あるいは脛骨 粗面に近い膝蓋腱などの触診による痛みのあ る箇所の断定を行う。さらに間歇性跛行、膝 蓋靶帯や膝蓋腱部分のクラッキングや:・腫、 いわゆるハムストリング筋や腓腹筋三頭の短
縮なども診断の助けになる。超音波やMRIも 補足的な診察に使われる。レントゲンは診断 に役にたたない場合もあるが、膝蓋骨の末端 の石灰化や骨刺を発見する場合の参考になる。 組織学的な診断では再生部分でのムコイド変 性、纎維素の壞死、繊維牙細胞や毛細血管の 增殖などが有効である。文献には広い範囲の 保存療法が書かれており、例えば部分的アイ シング、非ステロイド系消炎剤、ハムストリ ング筋や四頭筋のストレッチ、四頭筋の等尺 
運動、膝プロテクターの使用、ステロイドの 部分的な使用、運動を控えることなどである。 文献によるデータでは外来診療は病態に応じ て書かれておりステージ 1 と 2 では保存療法 で十分な効果があがるとされている。またス テージ 3 では少数の患者は保存療法で治癒す るが殆どの場合長時間の休息や、良い治療結 果が出るまで運動の回数を減らす必要がある。 Ferrretti、Blazina、Roelsらによると運動量 を減らさずに治療をしたい場合は外科的手術 を必要とする。多く外科的な治療術はステー ジ 3 から記述されている。ステージ 4 では外 科手術が必要になる、膝蓋腱の変性部分切除 と腱組織の移植から構成される。

良導絡治療は筋骨系のさまざまな痛みの症 状に使われてきた。しかし膝蓋腱炎の治療に 関する良導絡治療の参考文献は見付けること ができなかった。今回の研究の結果は承諾を もらった外来患者ステージ 3 の膝蓋腱炎で良 い治療結果を出した例の治療過程を発表する ことができた 43 例 $(74.1 \%)$ 。

良導絡治療で痛みがとれた後には、補足的 なリハビリテーション治療が必要である。そ れは運動治療学的測定、しばしば短縮してい ることが多いハストリング筋や腓腹筋のスト レッチを含む。等張筋と等尺筋の筋力のスト レッチは伸筋と屈筋の生理学的バランスを考 慮して行う必要がある。PNF (固有感覚療法) や体を良い状態に保つ事も同様に重要ある。 患者障害の有った部分の機能が100\%回復した 時は、以前のスポーツ活動の状態に戻れる様 に指導を受けるべきである。質問に回答があ つた41例の患者についての追跡調査の分析で は、良導絡の鎮痛効果が続いている。我々は 時間が経過することにより、痛みの強さが改 善した 8 例の患者について注目した。

\section{結 論}

良導絡治療はBlazinaの分類におけるステー シ 3 の膝蓋腱炎痛の治療に対して効果的な保 存的処置である。その結果は継続し、その応用 技術の簡易性、処置にかかるコストの安さと、 少ない治療回数で痛みを取ることができる確
立された方法をもっている。多くの患者 $74.1 \%)$ は以前のスポーツ競技に復帰している。

\section{参考文献}

1.AMATUZZI, M.M. : Epifinites da Rotula e Tibia. In Curso de Patologia do Joelho. Biblioteca do Instituto de Ortopedia e Traumatologia does HC da FMUSFP. Sao Pauro, p. 83-86, 1992.

2. BLAZINA, M.E. ; KARLAN, R. K. ; JOBE. F.W.CARTER, V.S.\& CARISON.G.J. Jumper's Knee. Orthop. Clin. North AM. no 4, p.665-678, 1973 .

3.CHAPMAN, R.S.\& SVRJALA.K.L. Measurement of pain; in BONICA, J. J. : The Management of pain.2nd ed., Londres, Leo \& Febiger, vol.1. Chapter32, p.580$594,1990$.

4.FERRETTI.A. APPOLITO.E. MARIANI. P.P. ; PUDDU. G. ; Jumper's Knee. AM. J. SPORTS MED.vIIn"2.p. 58-62, 1983.

5.FERRETI. A. ; PUDDU. G. ; MARIANI, P. P. ; NERI, M. : The natural history of Jumper's Knee. International Orthop.v.8, p. 239-242, 1985

6.FRITSCHV, D. ; GAUTAR, R. : Jumper's Knee and Ultrassonography. Am. J. Sports Med, v.16. No6, p.637-640,1988.

7.IMAMURA.S.T. Electroacupunctura no Jumper's Knee. Medicina de Reabilitacao, 15, p.9-11,1987

8.ISMAL, A.M. ; BLAKRISHMAN. R. ; RAJAKAMUR, M.K. ; Rupture of patellar ligament after steroid infiltration. J. Bone Joint Surg., v. 51-B, p.503-505, 1969.

9. MARTENS, M. ; WOUTERS, P. ; BURSSENS, A. ; MULIER. J.C. : Patellar Tendinitis : Pathology and Results as Treatment. Acta. Orthop. Scand. , 53, p. 445450, 1982.

10. NAKATANI. V. ; YAMASHITA, K, Ryodoraku Acupuncture. A guide for application of ryodorakyu therapy electrical acupuncture, a new autonomic nerve regulating therapy. Tokyo ed. Ryodoraku Research Institute, 1977

11. NICHOLS. C. E. : Patellar tendon injuries. Clin. Sports Med. ,11, n"4, p.807-813,1992.

12. ROELS. J. ; MARTENS M. ; MULIER. J.

C. ; BURSSENS A. : Patellar tendinitis (Jumper's Knee) . Am. J. Sports Med. ,6. N"6. P.362-368, 1978.

13. ROSENBERG. J. M. ; WHITAKER. J. H. : Bilateral Infrapatellar tendon rupture in a patient with Jumper's Knee. Am. J. Sports Med., 19, no1, p.94-95,1991. 
Speclal Lecture 1

\section{Treatment and Follow-up of the Patellar Tendinitis (Jumper's Knee) with Electroacupuncture Ryodoraku}

Satiko Tomikawa Imamura, M.D., PhD.

\section{Summary}

Patellar tendinitis is a common lesion in athletes who are involved in some type of repetitive activity of the extensor mechanism of the knee such as jumping, running, cycling or kicking. This study evaluated the therapeutic effects of electroacupuncture Ryodoraku on stage three of patellar tendinitis in 58 cases (66 knees). Complete relief of pain and return to previous activity level was observed in 43 patients $(74,1 \%)$. It was concluded that electrocupuncture Ryodoraku is an efficient method in treating patella tendinitis, of easy execution, and low cost, requiring only a few sessions to obtain pain relief.

\section{Key words}

Knee. Patellar tendon. Tendinitis. Electroacupuncture. Sports injuries. Analgesia.

\section{Introduction}

Patellar Tendinitis is a common lesion in athletes that repeatedly use the decelerating mechanism of the extending muscle of the knee.

The term "Jumper's Knee" was described by Blazina $(1973)^{(2)}$ for being extremely frequent in athletes that jump. This pathology was classified by Blazina and later modified by Roels $(1978)^{(12)}$ in 4 stages: stage 1 - pain in the beginning of the sporting activity; stage 2 - pain in the beginning of the activity that disappears after the warm-up and reappears after the end of the activity; stage 3 - persistent pain during and after the activity and the patient is unable to accomplish sports and stage 4 - when there is complete rupture of the patellar tendon. The patients refer pain when they stay a long time seated and they feel the need to extend the knee to relax the quadriceps muscle; they also refer pain when they crouch and when they go up and down stairways or slopes.

The purpose of this work is to demonstrate our experience using electroacupuncture Ryodoraku in the treatment of stage 3 patellar tendinitis.

\section{Material and Method}

The study includes 58 patients (66 knees), 40 being men and 18 women. The mean age was 26 years (17-50 years). The patients were referred by the orthopedic specialists and the duration of the pain, before the treatment with electroacupuncture was on average, of 14 months (1-84 months). All the patients were diagnosed with stage 3 of the classification of Blazina modified by Roels $(1978)^{(12)}$

In 32 of the cases $(55,1 \%)$, the right knee was affected, in $18(31,0 \%)$ the left and bilateral in $8(13,9 \%)$ (table 1$)$. The pain was located in the inferior pole of the kneecap in 38 knees $(65,5 \%)$, in the superior pole in $9(15,5 \%)$ and in both poles in 
$11(19 \%)$ (table 2). The sporting activities of these 58 patients were: running 16 $(28 \%)$, soccer $8(14 \%)$, gymnastics $7(12 \%)$, ballet $7(12 \%)$, volleyball $6(10 \%)$, tennis $4(7 \%)$, basketball $3(5 \%)$ and other $7(12 \%)$ (table 3$)$.

The evaluation of the intensity of the pain was accomplished by visual analogue scale (VAS) that consists of a line of $10 \mathrm{~cm}$ of extension that presents the nomenclature "pain absence" in an extremity and "unbearable pain" in the other.

The intensity of the pain was quantified through the measurement of a vertical line that crosses the horizontal line, depicted by the patient to indicate the intensity of the pain in a scale of 0 to $10^{(3)}$

All the patients of this study were previously subscribed to several treatments, without obtaining good results.

We used an apparatus of Japanese origin, Tormeter IW 5010B, needles of stainless steel, sterilized in the autoclave, and an appropriate needle injector.

Using the Tormeter IW 5010B we could detect the points of lowest electric skin resistance in the inferior and superior pole of the kneecap. The needle was introduced to these points in a perpendicular direction until reaching the periosteum. Through the needle, a continuous electric current, from 100 to 150 microAmperes, $12 \mathrm{~V}$ were applied for 7 seconds in each point. Two to four points in the superior and inferior poles were detected. Nakatani ${ }^{(9)}$ denominated reactive electro permeable points (points of lowest electric skin resistance) where the electric current flows with larger intensity. These points coincide in most of the cases with the points sensitive to palpation.

The number of sessions varied from 3 to 5 times a week. The duration of the treatment was from 2 to 5 weeks, according to the therapeutic answer. Thirty-five patients $(66 \%)$ received from 1 to 10 treatment sessions, 20 patients $(34 \%)$ from 11 to 20 sessions and 3 patients $(5 \%)$ more than 20 sessions.

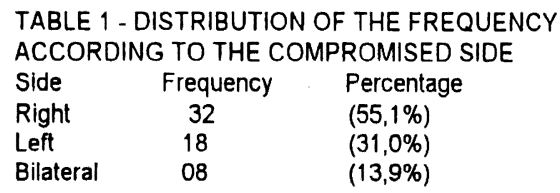

TABLE 2 - DISTRIBUTION OF THE FREQUENCY ACCORDING TO THE POLE

$\begin{array}{lcc}\text { Pole } & \text { Frequency } & \text { Percentage } \\ \text { Inferior } & 38 & (65,5 \%) \\ \text { Superior } & 09 & (15,5 \%) \\ \text { Both } & 11 & (19,0 \%)\end{array}$

$\begin{array}{lcc}\text { TABLE 3 } & \text { SPORTING } & \text { ACTIVITIES } \\ \text { Sport } & \text { Cases } & \text { Percentage } \\ \text { Race } & 16 & (28 \%) \\ \text { Soccer } & 08 & (14 \%) \\ \text { Gymnastics } & 07 & (12 \%) \\ \text { Ballet } & 07 & (12 \%) \\ \text { Volleyball } & 06 & (10 \%) \\ \text { Tennis } & 04 & (07 \%) \\ \text { Basketball } & 03 & (05 \%) \\ \text { Other } & 07 & (12 \%)\end{array}$

\section{Results}

The evaluation criteria established by us was the following: we considered Good result - when the patient came back to the previous activities, without pain; Regular - when the patient presented VAS 2-3 during the sporting and Bad - when the patient didn't present pain relief and he/she presented functional incapacity to return to the previous sporting activities.

Good results were observed in 43 patients $(74,1 \%)$; regular in 10 patients $(17,2 \%)$ and bad in 5 patients $(8,7 \%)$. The latter were referred for surgery The complete relief of pain occurred in 43 patients $(74,1 \%)$.

The follow-up was possible in $41(70,6 \%)$ of the 58 cases and was obtained through phone contact. The follow-up period varied from 3 to 169 months (mean = $72,0 \mathrm{mo})$. 
Of the 41 follow-up patients, $37(90,2 \%)$ represented complete relief of the pain (VAS =0). Out of the 37 patients, eight showed reduction in the intensity of pain with the elapsing of time. These patients represented mean VAS $=2,2(1-3)$ in the end of the treatment, achieving complete relief of the pain (VAS $=0$ ) for occasion of the follow-up. Three patients $(7,3 \%)$ didn't show any improvement. In one patient there was worsening in the intensity of the pain (table 4).

The mean duration of the asymptomatic period was of 73,1 months (3-169 mo), starting from the end of the treatment with electroacupuncture Ryodoraku (table 4).

\begin{tabular}{|c|c|c|c|c|}
\hline Initials & Sex & Age & Follow-up & $\begin{array}{l}\text { Evaluation of pain: end of } \\
\text { the treatment and follow-up }\end{array}$ \\
\hline 1) & $M$ & 25 & $169 \mathrm{Mo}$ & VAS $=0 \rightarrow 0$ \\
\hline 2) & $M$ & 46 & $156 \mathrm{Mo}$ & VAS $=0 \rightarrow 0$ \\
\hline 3) & $M$ & 18 & $132 \mathrm{Mo}$ & VAS $=0 \rightarrow 0$ \\
\hline 4) & $M$ & 28 & $129 \mathrm{Mo}$ & VAS $=0 \rightarrow 0$ \\
\hline 5) & $M$ & 26 & $129 \mathrm{Mo}$ & VAS $=2 \rightarrow 0$ \\
\hline 6) & $M$ & 35 & $127 \mathrm{Mo}$ & VAS $=0 \rightarrow 0$ \\
\hline 7) & $M$ & 16 & $126 \mathrm{Mo}$ & VAS $=0 \rightarrow 0$ \\
\hline 8) & $F$ & 09 & $121 \mathrm{Mo}$ & VAS $=0 \rightarrow 0$ \\
\hline 9) & $M$ & 21 & $120 \mathrm{Mo}$ & VAS $=0 \rightarrow 0$ \\
\hline 10) & $\mathrm{F}$ & 25 & $119 \mathrm{Mo}$ & VAS $=2 \rightarrow 0$ \\
\hline 11) & $\mathrm{F}$ & 29 & $118 \mathrm{Mo}$ & VAS $=4 \rightarrow 6$ \\
\hline 12) & $M$ & 28 & $118 \mathrm{Mo}$ & VAS $=0 \rightarrow 0$ \\
\hline 13) & $M$ & 38 & $112 \mathrm{Mo}$ & VAS $=0 \rightarrow 0$ \\
\hline 14) & $M$ & 44 & $81 \mathrm{Mo}$ & VAS $=0 \rightarrow 0$ \\
\hline 15) & $M$ & 29 & $80 \mathrm{Mo}$ & VAS $=0 \rightarrow 0$ \\
\hline 16) & $\mathrm{F}$ & 50 & $78 \mathrm{Mo}$ & VAS $=1 \rightarrow 0$ \\
\hline 17) & $M$ & 19 & $78 \mathrm{Mo}$ & VAS $=0 \rightarrow 0$ \\
\hline 18) & $F$ & 47 & $77 \mathrm{Mo}$ & VAS $=0 \rightarrow 0$ \\
\hline 19) & $F$ & 49 & $72 \mathrm{Mo}$ & VAS $=0 \rightarrow 0$ \\
\hline 20) & $M$ & 20 & $68 \mathrm{Mo}$ & VAS $=0 \rightarrow 0$ \\
\hline 21) & $M$ & 22 & $64 \mathrm{Mo}$ & VAS $=0 \rightarrow 0$ \\
\hline 22) & $F$ & 50 & $60 \mathrm{Mo}$ & VAS $=0 \rightarrow 0$ \\
\hline 23) & $F$ & 50 & $57 \mathrm{Mo}$ & VAS $=3 \rightarrow 0$ \\
\hline 24) & $F$ & 17 & $53 \mathrm{Mo}$ & VAS $=2 \rightarrow 2$ \\
\hline 25) & $M$ & 23 & $48 \mathrm{Mo}$ & VAS $=3 \rightarrow 0$ \\
\hline 26) & $M$ & 37 & $46 \mathrm{Mo}$ & VAS $=0 \rightarrow 0$ \\
\hline 27) & $\mathrm{F}$ & 48 & $43 \mathrm{Mo}$ & VAS $=0 \rightarrow 0$ \\
\hline 28) & $\mathrm{F}$ & 25 & $43 \mathrm{Mo}$ & VAS $=2 \rightarrow 2$ \\
\hline 29) & $\mathrm{F}$ & 42 & $42 \mathrm{Mo}$ & VAS $=0 \rightarrow 0$ \\
\hline 30) & $M$ & 17 & $41 \mathrm{Mo}$ & VAS $=0 \rightarrow 0$ \\
\hline 31) & $M$ & 50 & $36 \mathrm{Mo}$ & VAS $=2 \rightarrow 0$ \\
\hline 32) & $\mathrm{F}$ & 50 & $36 \mathrm{Mo}$ & VAS $=0 \rightarrow 0$ \\
\hline 33) & $F$ & 19 & $32 \mathrm{Mo}$ & VAS $=1 \rightarrow 1$ \\
\hline 34) & $M$ & 50 & $28 \mathrm{Mo}$ & VAS $=0 \rightarrow 0$ \\
\hline 35) & $\mathrm{F}$ & 22 & $28 \mathrm{Mo}$ & VAS $=0 \rightarrow 0$ \\
\hline 36) & $M$ & 35 & $23 \mathrm{Mo}$ & VAS $=3 \rightarrow 0$ \\
\hline 37) & $M$ & 49 & $22 \mathrm{Mo}$ & VAS $=2 \rightarrow 0$ \\
\hline 38) & $M$ & 25 & $22 \mathrm{Mo}$ & VAS $=0 \rightarrow 0$ \\
\hline 39) & $F$ & 19 & 9Mo & VAS $=0 \rightarrow 0$ \\
\hline 40) & $M$ & 50 & $5 \mathrm{Mo}$ & VAS $=0 \rightarrow 0$ \\
\hline 41) & $\mathrm{F}$ & 27 & $3 \mathrm{Mo}$ & VAS $=0 \rightarrow 0$ \\
\hline
\end{tabular}

M, Male; F, Female; Mo, Months; VAS, Visual Analysis Scale Scale "

\section{Discussion}

The incidence of the patellar tendinitis has increased in the last years, probably due to a more intense sport practice and a better medical understading of this pathology.

The diagnosis is made by the physical examination that it is characterized by pain to the palpation of the kneecap in its inferior pole, medium third and/or superior 
pole (patellar ligament) or close to the tibia tuberosity (patellar tendon). The clinical manifestation of claudication, crackling and edema in the region of the patellar ligament or patellar tendon and shortening of muscles such as the hamstrings and triceps suralis help in the diagnosis. Complementary exams such as ultrasound and magnetic resonance imaging can be used. The radiological study is often negative, although in some instances calcifications or osteophytes in the extremities of the kneecap can be found. Histological examination reveals mucoid degeneration, fibrinoid necrosis and fibroblastic and vascular proliferation in regeneration areas.

There is a wide range of conservative treatments described in the literature including: local application of ice, non-steroid anti-inflammatory medication, stretching of the hamstrings and quadriceps muscles, isometric exercises of the quadriceps muscle, use of knee protectors, local infiltration with steroids and decrease of physical activity. The data of the literature demonstrate that the therapeutic outcome depends on the stage of the disease. The stages 1 and 2 seem to respond satisfactorily to the conservative treatment ${ }^{(5 .}{ }^{8)}$. In stage 3 , a minority of the patients becomes asymptomatic with conservative treatment. In most cases, a long period of rest and reduction of the frequency of the physical training is necessary to obtain good results ${ }^{(5)}$. According to Ferretti et al. (5), Blazina et al. ${ }^{(2)}$ and Roels et al. ${ }^{(12)}$, athletes that don't want to reduce their sporting activity should submit to surgical treatment. Many surgical techniques have been described for the treatment of the patellar tendinitis in stage $3^{(2.4 .12)}$ and the results of surgical treatment are variable ${ }^{(5)}$. The stage 4 always requires surgery, which consists of resection of the degenerated portion of the patellar tendon and tendon grafting.

Electroacupuncture has been used for the treatment of several pain syndromes in the musculoskeletal system. We did not find references in the literature on the treatment of patellar tendinitis with electroacupuncture Ryodoraku.

The results obtained in this study demonstrated favorable outcomes with this procedure in the treatment of the patellar tendinitis, stage $3.74 .1 \%$ (43 patients) obtained good results.

After pain relief with the electroacupuncture Ryodoraku, appropriate complementary rehabilitation treatment is indispensable. This consists of kinesiotherapeutic measures, including the stretching of the hamstrings and triceps suralis muscles that are usually shortened. The muscular strengthening with concentric and eccentric exercises, should aim at the physiologic muscular balance among agonistic and antagonistic muscles. The proprioception and physical conditioning are equally important. The patients should be guided to come back to the previous sporting activity, only when the affected segment comes to $100 \%$ of its functional capacity.

The analysis of the follow-up of 41 patients that replied to the inquiry, demonstrates that the analgesic effect of the electroacupuncture Ryodoraku is of long duration. We observed improvement in the intensity of the pain with elapsing of the time in eight patients.

\section{Conclusion}

The electroacupuncture Ryodoraku is an effective conservative procedure in the treatment of the pain of the patellar tendinitis in stage 3 of Blazina. The results are durable. The easiness in the application technique, the low operational cost and 
the small number of sessions necessary to obtain relief of the pain constitute advantages of the method. Most of the patients $(74,1 \%)$ returned to their previous sporting activities.

\section{References}

I. AMATUZZI, M.M.: Epifinites da Rótula e Tibia. In Curso de Patologia do Joelho. Biblioteca do Instituto de Ortopedia e Traumatologia do HC da FMUSP. São Paulo, p. 83-86, 1992.

2. BLAZINA, M.E.; KARLAN, R.K.; JOBE. F.W.; CARTER, V.S. \& CARISON. G.J.: Jumper's Knee. Orthop. Clin. North AM., no 4, p. 665-678, 1973.

3. CHAPMAN, R.S. \& SVRJALA. K.L.: Measurement of pain; in BONICA, J.J.: The Management of pain. 2nd ed., Londres, Leo \& Febiger, vol. 1. chapter 32, p. $580-$ 594, 1990.

4. FERRETTI. A.; APPOLITO. E., MARIANI. P.P.; PUDDU. G.: Jumper's Knee. AM. J. SPORTS MED. v.II, n"2. p.58-62, 1983.

5. FERRETTI. A.; PUDDU. G.; MARIANI, P.P.; NERI, M.: The natural history of Jumper's Knee. International Orthop. v.8, p. 239-242, 1985.

6. FRITSCHV, D.; GAUTAR, R.: Jumper's Knee and Ultrassonography. Am. J. Sports Med.. v.16. nO 6, p. 637-640, 1988.

7. IMAMURA. S.T. Eletroacupuntura no Jumper's Knee. Medicina de Reabilitação, 15, p. 9-11, 1987.

8. ISMAIL, A.M.; BALAKRISHMAN. R.; RAJAKAMUR, M.K.: Rupture of patellar ligament after steroid infiltration. J. Bone Joint Surg., v.51-B, p.503-505, 1969.

9. MARTENS, M.; WOUTERS, P.; BURSSENS, A.; MULIER. J.C.: Patellar Tendinitis: Pathology and Results as Treatment. Acta. Orthop. Scand., 53, p.445450, 1982.

10. NAKATANI. $V_{\text {; }}$ YAMASHITA, $K_{\text {; }}$ R Ryodoraku Acupuncture. A guide for application of ryodoraku therapy electrical acupuncture, a new autonomic nerve regulating therapy.

Tokyo ed. Ryodoraku Research Institute, 1977.

II. NICHOLS. C.E.: Patellar tendon injuries. Clin. Sports Med., 11, n"4, p.807-813, 1992.

12. ROELS. J.; MARTENS M.; MULIER. J.C.; BURSSENS A.: Patellar tendinitis (Jumper's Knee). Am. J. Sports Med.. 6. n"6. p.362-368, 1978.

13. ROSENBERG. J.M.; WHITAKER. J.H.: Bilateral Infrapatellar tendon rupture in a patient with Jumper's Knee. Am. J. Sports Med., 19, no 1, p.94-95, 1991. 